\title{
Socio-Cultural Heritage For Tourism At Cirebon Palaces, Indonesia
}

\author{
INA HELENA AGUSTINA \\ Department Of Urban and Regional Planning, Faculty Of Engineering, Universitas Islam Bandung, Indonesia \\ Correspondence author: inahelena66@gmail.com
}

\begin{abstract}
In Cirebon, there are three palaces, namely Keraton Kasepuhan, Keraton Kanoman, and Keraton Kacirebon. Until now, the three palaces still show their existence through tourist attractions, especially pilgrimage tours. Pilgrimages to the tomb of Sunan Gunung Jati, as one of the Walisongo (nine propagators of Islam in Java) and also the ancestors of the three palaces, still attract visitors to visit the palace. This research aims to explore the socio-cultural attractions of the Cirebon palaces for tourists The research method used is the Husserl Phenomenology method. Phenomenology is a way of thinking or "the style of thinking" with objects that are symptomatic in the form of facts or symptoms, circumstances, events, objects, or reality. Construction through physical space, socio-cultural and economic attractiveness. The result is a tourist attraction with a unique local value in the form of "blessings". The value of the uniqueness of a tourist attraction is different from other royal tourist objects, but these local values must be determined as an intangible heritage element of tourist attraction. These results can serve as recommendations for the conservation of the palaces in Cirebon.
\end{abstract}

Keyword: tourism, heritage, keraton, cirebon

\section{Introduction}

Indonesia is a country with numerous cultures. Culture is formed from the kingdoms that once stood in the past. Most of the kingdoms have become extinct but some still survive with their status as cultural heritage, such as the palaces in Cirebon

Currently, the palace in Cirebon City consists of Keraton Kasepuhan, Keraton Kanoman, and Keraton Kacirebonan [Agustina, 2019]. The three palaces come from one lineage, namely Sunan Gunung Jati. He is a member of the Walisongo (nine wali) known as the propagator of Islam in Java, he is also the most powerful king in the Sultanate of Cirebon [Agustina, 2019]. In the 16th century, the Cirebon Sultanate was divided into 3, namely Keraton Kasepuhan, Keraton Kanoman, and Keraton Kacirebonan [Agustina,2019]. In contrast to the past where the palaces served as the center of government and strength of an area, currently, it is only a symbol of royal history/cultural heritage. The role and symbols of the past become one of the palace's tourist attractions.

The three palaces have different management according to the authority of each Sultan (Sultan is the title for the king in the Cirebon Palace). Tourists become the source of finance for the continuity of the palace. The management of the palace needs money for the maintenance of ancient buildings, electricity, traditional ceremonies, and fees for the abdi dalem. The palace still has Abdi Dalem (Abdi Dalem is the term for employees who work in the palace) who are loyal to their duties even though their income is very small. The loyalty of abdi dalem and the ability of the palaces to survive with all the preservation efforts, especially the traditions, are interesting phenomena and knowledge to learn. This aspect is an intangible phenomenon that needs to be explored.

Research on the Cirebon palaces has been carried out by researchers since 2010, namely: The Shift in the Meaning of Symbolic

Received: 2020-10-26, Revised: 2020-10-26, Accepted: 2020-12-12 
Space to the Pragmatic Room of Keraton Kasepuhan Area in 2010-2015; Magersari Settlement Study 2016; Study of the Space Meaning of Keraton Kanoman and Keraton Kacirebonan in 2017-2019. All studies were conducted with a phenomenological approach but focused on the meaning of space. This research was carried out with a phenomenological approach but emphasized the aspect of tourism. The tourism aspect has not been the focus of previous studies. Research on the tourism of the Cirebon palaces has been done a lot but it concerns more on promotion and marketing using a rationalistic paradigm. A phenomenological approach has never been carried out by previous studies, especially to explore intangible attraction for tourism. To fill this void, this research aims to explore the socio-cultural attractions of the Cirebon palaces for tourists. The findings became material for intangible knowledge for the conservation of the palace area in Cirebon.

Jing (Bill) Xu, Tsz Ling (Elaine) Chan \& Stephen Pratt [2017] stated that in developing the image of tourist destination, it turns out that the effective image is an important intangible quality for the destination.

The tourist destinations of Cirebon palaces offer religious or spiritual tourism. The spiritual and religious traditions that create silence are considered suitable for health care [Lynn Bassett, Amanda F. Bingley, and Sarah G. Brearley, 2018]. The development of modernity and globalization has resulted in an "empty secular society" [Tacey, 2004, p. 2] and hence the concept of spirituality [Giordan, 2009]. This feeling of emptiness has influenced individuals to seek well-being and self-discovery [Kale, 2004]. Individual spirituality is about self-development. For self-development, one needs to connect with their spiritual/inner self. Tourists for religious tourism are individuals who seek individual spirituality, and practice spirituality for personal growth, either by finding God, getting closer to God, or actualizing/getting closer to their inner self. For them, spirituality is a source of transcendence and/or a search for meaning [Moufakkir,\& Noureddine Selmi, 2017].

This shows that the awareness and impression of a place become an important aspect for tourists. In addition, the value related to the quality itself has link to the tourist loyalty to destinations [Saeedi \&Kambiz Heidarzadeh Hanzee; 2016]. Therefore, in maintaining its image as a tourist destination, the palace needs to pay attention to the impressions and quality values expected by tourists. The image can be developed through the concept of heritage branding, such as India developing heritage branding under the name Ghandi [Chhabra, 2017].

According to Timothy [Timothy \& Stephen W. Boyd; 2008], palace tourism is heritage tourism that has a value. Heritage venues and events are also commonly used as tools to build nationalism and patriotism among domestic tourists [Timothy \& Stephen W. Boyd; 2008]. According to the statement, it is true that palace tourism is a tour that must build the value of tourism nationalism, which is the nationalism of loving native culture.

\section{Research Methodology}

Research in the Cirebon Palace Area has been conducted since 2010 until 2019. The research methodology uses the phenomenology of Husserl [Agustina, 2019]. Phenomenology is present as a result of the epistemological crisis carried by the existing knowledge paradigms in the west. The purpose of the crisis is the narrowing of knowledge due to methodological reductions which are accompanied by fragmentation and instrumentalization of knowledge. The crisis occurred because of the results of the development of modernization in the West which undermined the order of the value of medieval society [Agustina,2019]. Husserl's phenomenology emphasizes what appears in experience will formulate the essence. Husserl has achieved a breakthrough for determining and connecting intentional content ideas with the right typology of action [Welton, 2003]. The stages of using this research method are as follows: seeing the phenomenon as a whole; in-depth observation on the existing space and cultural system; building personal relationships with the space system; focus on an understanding of existing meanings because they are done continuously or intentionality in the field; incorporation of information obtained.

From these stages, it can be produced: (1) grouping information units, information units obtained from the results of field grand tours; (2) establishing empirical themes from information units, then constructing concepts based on these empirical themes. The results of this study produce units of information such as (1) history, (2) tradition, (3) physical space, (4) social relations, (5) tourists, and (6) Palace Policy. Then it produces an empirical theme of (1) physical spatial, (2) economic 
activity, and (3) social-cultural. Based on these empirical themes, construction can be drawn from the attractiveness of the Cirebon palaces.

\section{Results and Discussion}

Empirically, Husserl's phenomenology method produces the following empirical themes:

\section{Physical Spatial}

The palaces in Cirebon have a history related to the spread of Islam in the western part of Java. The image of Sunan Gunung Jati as the spreader of Islam and the king of the Cirebon Sultanate is still inherent in the minds of the people today. His figure as a holy man and bringing the blessings of life to the ummah is still inherent in the people of Cirebon. The existence of evidence such as tombs, buildings, kings and their descendants made the figure of Sunan Gunung Jati continue to live in the Cirebon Palace until now.

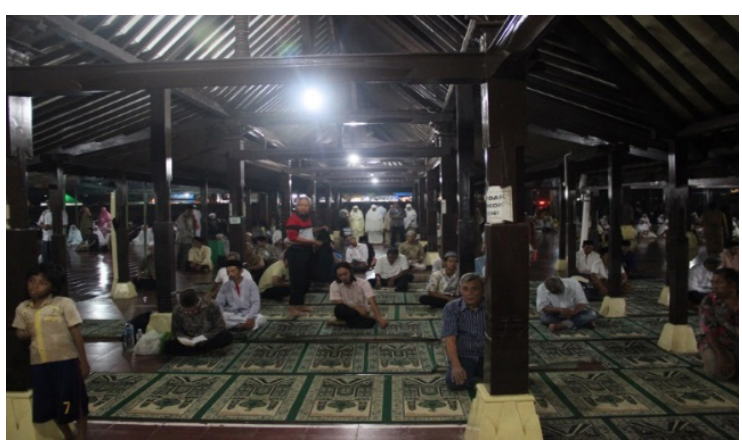

Figure 1. Muludan event visitors (panjang jimat) in Keraton Kasepuhan. Waiting for a panjang jimat ceremony in Sang Cipta Rasa Mosque.

Source: Agustina, 2019

Evidence of the recognition of the existence of the palaces can be seen from the phenomenon of community visits to the palaces, especially in the procession of esoteric traditions held by the palace (see figure 1). The existence of the palaces in Cirebon relates to the Islamic beliefs that developed in the community. The image of Sunan Gunung Jati can be considered as a destination brand image to attract tourists, such as the statement of [Saeedi, Hamid \& Kambiz Heidarzadeh Hanzaee,2016]:

"brands are extremely influential in marketing, destinations should work to develop strong and recognizable brands for tourism to succeed in differentiating their competitive advantages over other destinations "
Religious tour in Cirebon palaces is a tour with a unique culture, therefore if it continues to be maintained it will provide tourism competitiveness. The religious tourism activities of the Cirebon palaces are known through word of mouth information systems. In the future, this tour must be managed better.

The palaces in Cirebon become tourist destination objects. Palace rooms and buildings still become tourist attraction, because of the unique shape and history of the building. The palace spaces in Cirebon are located close together as shown in the following figure 2 . In addition to the location of the palace, there is the tomb location of Sunan Gunung Jati which is located in the northern part of the palaces. The distance from the palace to the tomb of Sunan Gunung Jati is $7 \mathrm{~km}$ away.

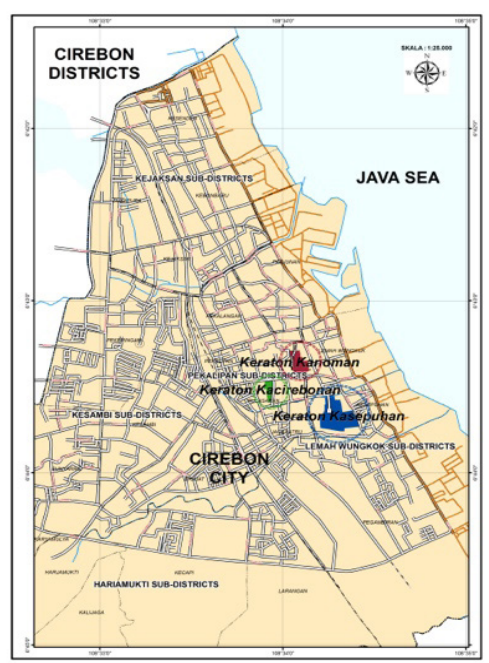

Figure 2.The Position of Keraton Kasepuhan, Keraton Kanoman, and Keraton Kacirebonan

Source: Agustina, 2019

The tomb is a tourist attraction that is visited by many tourists as well. The palace room is a building that has a dividing wall called the palace fort. The palace-fort is a barrier for the interaction between the palace activities and outside the palace. The palace-fort is called Kuta Kosod. Both palace rooms and buildings have unique names. The display room of the palace is named Siti Ingil. In the past, this space was the place for palace entertainment for its people. At present, it is only part of the tourist attraction in these palaces. Of the three palaces, only the Keraton Kacirebonan does not have a 
Siti Inggil room. Keraton Kasepuhan has a wider Siti Ingil room compared to the Keraton Kanoman room. Palace rooms and buildings with the characteristic of the walls with ancient plates of the past are still the main attraction of tourists until today (see figure 2 , figure 3 ).

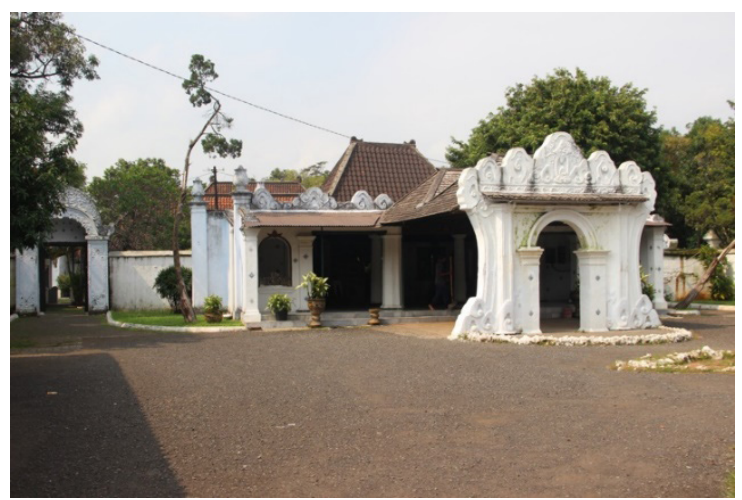

Figure 3. Kuta wadasan Building, the front side of the main building of Keraton Kasepuhan decorated by ancient plates.

Source: Agustina, 2019

\section{Socio-Cultural}

The palaces in Cirebon still retain old esoteric traditions. This tradition attracts tourists who will make pilgrimages and follow traditional processions. The tradition most witnessed by the community is the tradition of the prophet's born day. This tradition is known as the Panjang Jimat tradition and Friday Kliwon [Agustina, 2017). The timetable for the tradition of Panjang Jimat began on the 1st - 12th of the month of Mulud. The schedule for the implementation of the esoteric tradition follows the calendar in the year of Hijriyah [Agustina, 2017]. While the schedule for implementing Friday Kliwon follows the calendar of days according to the Javanese calendar. The Panjang Jimat tradition is a tradition of praying together to commemorate the birth of the prophet Muhammad SAW. The highlight of the event was at 8-11 p.m. by praying for talisman rice and then the rice was distributed to visitors/tourists who had been waiting for the talisman rice. Talisman rice is a palace specialty, a palace in Cirebon. Talisman rice is made from rice and spices ingredients that are rich in flavor. Whereas the traditional procession of Friday Kliwon is a tradition of tawasulan, which is a procession of dhikr and praying for the ancestors of the palace.

All procession of traditions is carried out voluntarily by visitors/tourists pilgrims and guided by palace officials. Tourist pilgrims believe this procession brings their goodness and blessing to life. Blessing is a focus on the spirituality and religiosity of individual/ human life [C. Gaventa, 2001; Jones et al; 2016]. This belief continues to emerge among pilgrims/tourists in Cirebon palace. The procedure for the procession of tradition is in accordance with the procedures used to be carried out by the ancestors of the palace. This means that the procedure of this tradition continues today.

Tour Activity in Cirebon palaces offers a spirituality attraction experience. Spirituality does not have a generally agreed definition [Koenig, 2012]. Spirituality is associated with relationships with nature or higher beings [Reich, 2000; Lynn, et all; 2011], with self-meaning in a broader ontological context, and is characterized by a constant search for meaning and purpose in life [Kale, 2004; Bregman, 2006; Dent et al., 2005; Hodge \& McGrew, 2006; McSherry \& Cash, 2004; Unruh, Versnel, \& Kerr, 2002]. Chiu, Emblen, Van Hofwegen, Sawatzky, and Meyerhoof (2004) identified four components of spirituality: (a) reality or existential meaning and a way of life, (b) transcendence, (c) connection and wholeness, and (d) the presence of a unifying force or energy. Spiritual tourism is considered a source of spiritual meaning or refreshment [Sharpley \& Jepson, 2011].

The data of tourist visits which managed by the palace shows that the amount of tourist arrivals is $25.000-35.000$ people/month, while foreign tourists as many as 200-500 people/month. The number of tourist arrivals increased rapidly from 2015, especially after the construction of Cipali Toll Road. The toll road connects major cities such as Jakarta and Bandung to the city of Cirebon.

Kasepuhan Palace has a relatively broad social relationship compared to the other two palaces. This phenomenon can be seen from several national-level activities involving the Kasepuhan Palace. Even Sultan Keraton Kasepuhan is the Chairperson of the Keraton Nusantara Silaturahmi Forum (FSKN) [Agustina, 2019]. However, the other two palaces also have different social relations. Keraton Kacirebonan has social relations with certain vehicle hobby communities. Kanoman Palace has social relations with the government in Cirebon City. The three palaces also have different policies in managing the palace. Kasepuhan Palace received a lot of funds from 
various entrepreneurs for the development of the Palace, even in 2017, the Pusaka Museum was built as a result of cooperation with the private sector (see figure 4). While the other palaces still rely on independence for the development of the palace.

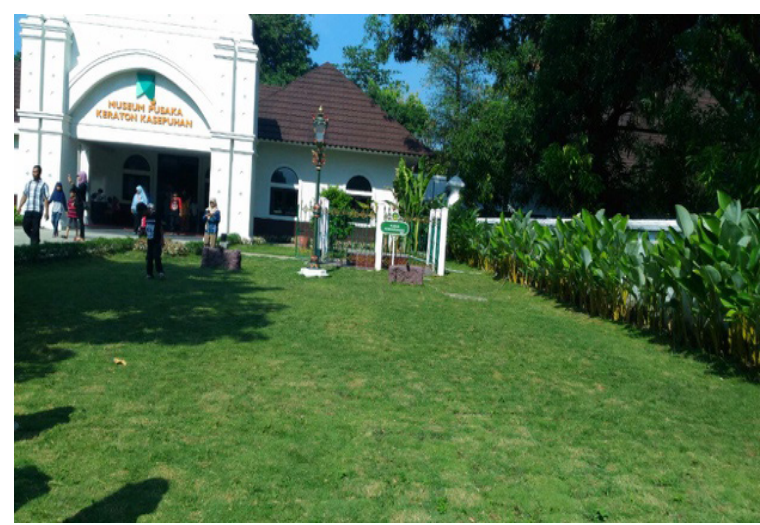

Figure 4. Museum of Pusaka Keraton Kasepuhan (Heritage of Kasepuhan Palace)

Source: Agustina, 2019

The three Keraton share a similarity in their social structure. All of them have abdi dalem as the social relationships form within Keraton. Abdi Dalem are the people who devoted themselves to give their service to Keraton. One of the main duties is to serve the tourist who attends the Keraton area. The common name for abdi dalem within keraton is 'wargi' which has a meaning of 'family'. This name reflects that abdi dalem is part of Keraton family. Each abdi dalem earns some money which is provided by Keraton in the form of 'paringan.' The number of earnings that abdi dalem get is below the minimum regional income of Cirebon city. For abdi dalem, their service is more important compared to the income they get. Their allegiance is based on their believe in the existence of the king and Keraton.

Besides engaged in the activity within Keraton, abdi dalem is also responsible for the activity at the Keraton King's burial site. The burial site is located $7 \mathrm{~km}$ to the north from the Keraton. It is called Astana Gunung Jati, where Astana is the name of the village where the burial site is located and Gunung Jati is named after Sunan Gunung Jati. Abdi dalem who responsible for the burial site activities are called Jeneng and Bekel. A Jeneng leads a group of Bekel and is responsible to make a working schedule. Usually, a Jeneng is leading a hundred person of Bekel. In each working schedule, the group has to stay at the burial site and their daily needs are provided by
Keraton. A group is replaced by another group every Friday. There is a ritual in the process of group replacement. Jeneng and Bekel are appointed and dismissed by the kings of two Keraton, Keraton Kasepuhan, and Keraton Kanoman.

The burial site is located on the hill terrain owned by Keraton Kanoman and Keraton Kasepuhan. The deceased kings of both Keraton are buried in this site. For the kings from Keraton Kacirebonan the burial site is located at the right side of the area owned by Keraton Kanoman. The burial site has nine doors with a unique name for each door. The first door is named Gapura, the second door is Kapyak, the third door is Pasujudan, the fourth door is Ratna Komala, the fifth door is Jinem, the sixth door is Rararongga, the seventh door is Bacem, and the ninth door is teratai. The ninth door is the gate to enter the peak of the burial site. There is only a limited area that can be entered by visitors.

There is a certain ritual during the pilgrimage to the grave of Sunan Gunung Jati. Firstly, the visitors have to make a wudhu to cleanse them in order to do the prayer. In the burial site, there is a facility to make a wudhu which is located on the right side of the entrance gate. The facility consists of big barrels which are filled with water. Secondly, the visitors have to take off their footwear before entering the 'pasujudan' area. Each visitors put themselves in the pasujudan area to perform prayer. The prayer has to face the burial site. Usually, the prayer is in the form of dzikr and part of the Quran which is guided by Bekel. Although this ritual is sacred, there is no written guidance to do this ritual at the burial site. So, the visitor has to rely on the guidance of Bekel.

Keraton and Astana become an important object for the traditional Islamic community. This believe is shared from generation to generation which considers Keraton and Astana as 'berkah'. As long as this believe still exists, there is always an attraction which brings the visitor to Keraton and Astana. Besides Islamic traditional community, there is also a growing fanaticism to this believe in modern society which increases even more the number of visitors to these objects. This growth is supported by the fact that modern belief is dominated by rationality. Therefore, it is important to conserve the traditional value of Keraton in Cirebon to maintain its attractiveness.

Not all the kingdom in Indonesia has 
the same uniqueness as that one at Keraton in Cirebon. This unique phenomenon is supported by the perception of the community that surrounds the life of Keraton to the existence of the king and Keraton. In order to conserve this tradition and cultural asset, support from the government, and Keraton itself is vital.

\section{Economic Activities}

Palace activities require a large amount of money. Financing is issued for palace operations such as salaries for courtiers, electricity, maintenance of old buildings, and traditional activities. The city and provincial government allocated funds for the palace, but the funds could not meet the operational needs of the palace. In addition, the Sultan and his family must carry out their real life. Thus the palace runs various businesses, apart from business as a tourist attraction. The effort carried out by the Keraton Kanoman was to rent the land to Kanoman market, but the impact on the Keraton Kanoman was that it was difficult to get access to the road because of the market activity. Apart from that, market activity has reduced the cleanliness of the Keraton Kanoman. The Keraton Kacirebonan economic activities are running a cafeteria, having Sekar Pandan dance studio and souvenir shop in the palace. Even the cafeteria at Keraton Kacirebonan is very much in demand. Keraton Kasepuhan has a Pakungwati school located at Sunyaragi. Of the three palaces, only Keraton Kasepuhan is managed by a relatively high ticket system compared to the other three palaces. Even tickets sold have been divided into palace entrance tickets and heritage museum entrance tickets. All of these economic activities aim to maintain the sustainability of the palace.

\section{Empirical Themes and Concept Find- ings}

The explanation of empirical themes above was found inductively in the Cirebon Royal Palace. Husserl's methodology is the transcendental phenomenology of a research object, namely the palace room, buildings, and space systems that are formed such as traditional activities, tourists, and courtiers. The phrase "blessing" was uttered by all tourists and courtiers of the Keraton Cirebon.

In addition, they (tourists) believe the palaces are places that have the power to grant their wishes and prayers. Signs like this show a phenomenon of transcendental awareness in the form of an awareness of "blessings". Blessings mean God's gift that brings good to human life, self-control to the obedience of a religious belief and inner potential [Stark, et al, 2005; Hubert, 2010, Barber, Christopher, \& Peter Kevern, 2011; Lasair, 2018]. Thus, the findings of the concept of Keraton Cirebon tourist attraction are "blessings".

The concept distinguishes the tourist attraction of heritage palaces in Cirebon with other tourist attractions, as well as the tourist attraction of the palace in Indonesia. The attraction of the palaces in Cirebon shows a concept of transcendental awareness, namely the concept of blessing.

\section{Theoretical Dialogues and Construc- tion of Tourist Attraction in The Pal- aces of Cirebon}

The palaces in Cirebon have a history that can provide knowledge to tourists. These palaces have become heritage attractions because heritage tourism sometimes involves visiting historic places [Kalman, 2014]. The phenomenon of Cirebon palaces as tourist destinations is encouraged by their past image that is Sunan Gunung Jati figure. This image is very important even $\mathrm{Xu}[\mathrm{Xu}$, Chan, and Stephen Pratt: 2017] revealed that in developing tourism image destinations, it turns out that the effective image is an important intangible quality for the destination. The effective image that appears in Cirebon Palace is the feeling of blessing and that is proof of the value of the attractions of palaces.

The impression and sensation which are subjective is an intangible value of Keraton in Cirebon. As long as this intangible value is maintained inside the Keraton community, tourists will be attracted to visit the Keraton. Keraton itself is the main actor to maintain this impression and sensation of its space. Impression and sensation were built through the environment of Keraton's space and the old tradition of Keraton. Therefore, Keraton has to preserve its tradition to preserve its attractiveness.

The preservation process of Keraton's old tradition is a part of the transmission process. The transmission process inside the Keraton community is also known as "getok tular". "Getok Tular" is a learning process by emulating the old generation and play a role in the tradition of Keraton. There is no formal institution that has a function to educate the 
young generation. The knowledge is passed from the old generation to the younger generation through the abdi dalem or wargi Keraton as the form of loyalty to the king.

This is also the case for the argument of impression and sensation of "keberkahan", which is passed from generation to generation. An argumentation of "keberkahan" is passed by the old generation through their personal experience about "keberkahan". It is a unique taste sensation that affects the behavior of human life in the form of natural awareness and becomes a search for purpose and a yearning for transcendental meaning [Kim, Sangwon \&. Giselle B. Esquivel, 2011].

The different purposes of the king compared to the old times raise the importance of the support from abdi dalem/wargi and its community. In the past, kings were considered as the messenger of gods who has magical power from their relics. Today, the king's only power comes from the belief of its loyal community. King is not supposed to isolate his life to maintain support from his people. This is also the case for Keraton in Cirebon, although the king still has charisma as a descendant of Sunan Gunung Jati, he has to be open to the change without forgetting the tradition from the ancestors. It is reflected in Keraton acceptance to the government or other institutions to build new facilities inside Keraton's area. The purpose of these facilities is to support the tourism of Keraton such as the Building of Relics in Keraton Kasepuhan and Pulantaran Building in Keraton Kanoman.

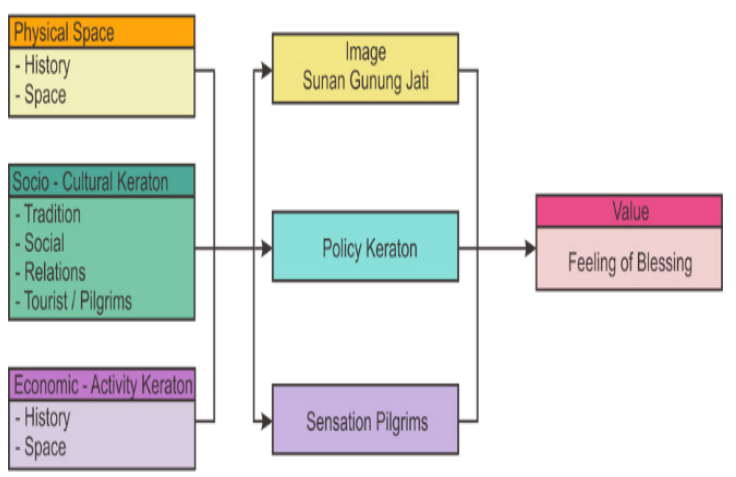

Figure 5. Heritage Attractions of Cirebon Palaces, Indonesia

The heritage of Keraton in Cirebon is not only limited to the physical of its space but also the attribute of the activities inside. It is reflected by the results of emerging empirical themes such as spatial, socio-cultural and economic activities that can construct the attractiveness of the Cirebon palaces is the value of blessing from these palaces. The value of blessing was built by Sunan Gunung Jati figure and followed up through the policies of his sultans by carrying out the activities of esoteric traditions consistently. Sunan Gunung Jati has potential heritage branding for tourism in Cirebon palaces because heritage branding has a big influence on tourist attraction. Even India has developed heritage branding to promote tourism to be cooperated with UNSECO [Chhabra, 2017]. More details on the heritage tourist attractions in the palaces in Cirebon can be seen in Figure 5.

The result of construction in tourist attractions of the palaces in Cirebon contributes to maintaining the existence of the palace. In Indonesia, there are 189 palaces/kingdoms, but not all palaces can maintain their existence. The effort to maintain the existence of the palace is to maintain the local culture which becomes the character of the Indonesian Nation. Forming the characteristic of a tourist attraction is not easy, especially when it is demanded to be able to attract tourists. Palace attractions that are old buildings from the legacy of the past must be able to compete with new attractions that are more attractive. The construction of attraction of the palace in Cirebon shows the uniqueness, which is the concept of "blessing" that will attract tourists to continue to be interested and visit these Cirebon palaces.

\section{Conclusions}

The phenomenon of the tourist attractions of the palaces in Cirebon is interesting to be the material for the study of scientific articles, especially the challenges of globalization being the challenge of the palace to continue to increase its attractiveness. The main attractiveness of the palaces in Cirebon includes space, buildings, and activities that will attract tourists. These assets of a palace (including tradition) should be maintained by taking care of its sustainability. However, the palace has significant obstacles and is not enough to rely solely on funding from tourists. Palace must develop other businesses, which certainly have risks to changes in assets they have. The construction of the heritage attraction of the palaces is the value of blessing that arises from the empirical physical space, socio-cultural themes, and economic activities with the image of Sunan Gunung Jati and the sultan's policy actions that consistently maintain esoteric traditions. 
The construction of tourist attractions in Keraton Cirebon can be used as an example for other palaces in maintaining the existence of the palace. The effort to explore the local construction of the palace is a way to build the characteristics/uniqueness of a palace so that it can survive in the competition of the tourist market.

\section{References}

Agustina, Ina Helena, (2017), "Exploring the Heritage Value of Space in Sang Cipta Rasa Mosque", Keraton Kasepuhan, Jurnal Mimbar Volume 33 (2), 426-436.

Agustina, Ina Helena (2019), Makna Ruang Keraton Kanoman dan Keraton Kacirebonan, Bandung, P2U Unisba.

Barber, Christopher, \& Peter Kevern (2011) Spirituality and the Needs of Those with Autistic Spectrum Conditions: So me Implications for 'Spiritual Care' Policies, Journal for the Study of Spirituality, 1:2, 203-214.

Bassett, Lynn, Amanda F. Bingley and Sarah G. Brearley, (2018), "The Contribution of Silence to Spiritual Care at The End of Life: A Phenomenological Exploration From The Experience of Palliative Care Chaplains", Journal For The Study of Spirituality, Vol 8 No. 1, 34-48.

Bregman, L. (2006). Spirituality: A glowing and useful term in search of a meaning. OMEGA, 53(1/2), 5-26.

C. Gaventa, William Jr MDiv (2001) Defining and Assessing Spirituality and Spiritual Supports, Journal of Religion, Disability \& Health, 5:2-3, 29-48

Chhabra, Deepak, (2017), "Heritage Branding of India: A Gandhi Tourism Perspective", Annals of Tourism Research 62, P 110116.

Chiu, L., Emblen, J. D., Van Hofwegen, L., Sawatzky, R., \& Meyerhoff, H. (2004). An integrative review of the concept of spirituality in the health sciences. Western Journal of Nursing Research, 26, 405-428.

Dent, E. B., Higgins, E., \& Wharff, D. M. (2005). Spirituality and leadership: An empirical review of definitions, distinctions, and embedded assumptions. The Leadership Quarterly, 16, 625-653.

Giordan, G, (2009), "The Body Between Religion and Spirituality", Social Compas, 56(2), 226-236.

Hodge, D. R., \& McGrew, C. C. (2006). Spirituality, religion, and the interrelationship: $A$ nationally representative study. Journal of Social Work Education, 42, 637-654.

Hubert, Knoblauch, (2010). 'Popular Spirituality'. In Anthropological Journal of European Cultures 19, no. 1: 24-39.

Jones, Janice, Annie Topping, John Wattis \& Joanna Smith (2016) A Concept Analysis of Spirituality in Occupational Therapy Practice, Journal for the Study of Spirituality, 6:1, 38-57.

Kale, S, (2004), "Spirituality, Religion, and Globalization", Journal Of Macromarketing, 24, 92-107.

Kalman, H, (2014), "Heritage Planning Principles and Process", London and New York, Routledge.

Kim, Sangwon\&. Giselle B. Esquivel. (2011). "Adolescent Spirituality and Resilience: Theory and Educational Practices". Psychology in the Schools, Vol. 48(7), 2011 Wiley Periodicals, Inc

Koenig, H. G, (2012), "Religion, Spirituality, and Health: The Research and Clinical Implications", International Scholarly Research Network ISRN Psychiatry, 1, 1-33.

Lasair, Simon (2018) Spiritual care as a secular profession: politics, theory, and practice, Journal for the Study of Spirituality, 8:1, 5-18.

Lynn Gall, Terry ,Judith Malette \& Manal Guirguis-Younger (2011): "Spirituality and Religiousness: A Diversity of Definitions", Journal of Spirituality in Mental Health, 13:3, 158-181.

McSherry, W., \& Cash, K. (2004). The language of spirituality: An emerging taxonomy. International Journal of Nursing Studies, 41, 151-161.

Moufakkir, Omar, \&Noureddine Selmi, (2017). "Examining The Spirituality of Spiritual Tourists: A Sahara Desert Experience", Annals of Tourism Research $x x x(x x x x)$ $x x x-x x x$.

Reich, K. H, (2000), "What Characterizes Spirituality? A Comment on Pargament, $S$ and Crumpler, and Stifoss-Hansen", International Journal for the Psychology of Religion, 10(2), 125-128.

Saeedi. H and Kambiz Heidarzadeh Hanzaee, (2016), "The effects of heritage image on destination branding: an Iranian perspective", Journal of Heritage Tourism, Published online: 14 Dec 2016, Publisher: Routledge, PP 1-15.

Sharpley, R., and Jepson, D, (2011), "Rural Tourism: A spiritual experience?", Annals of Tourism Research, 38(1), 52-71.

Stark, Rodney, Eva Hamberg and Alan S. 
Miller. 2005. 'Exploring Spirituality and Unchurched Religions in America, Sweden, and Japan'. Journal of Contemporary Religion 20, no. 1: 3-23.

Tacey, D, (2004), "The spirituality revolution: The emergence of contemporary spirituality", New York, NY: Springer.

Timothy, D.J, and Stephen W. Boyd, (2008), "Heritage Tourism in the 21st Century: Valued Traditions and New Perspectives", Journal of Heritage Tourism Publication details, Published online: 22 Dec 2008.

Unruh, A. M., Versnel, J., \& Kerr, N. (2002). Spirituality unplugged: A review of commonalities and contentions, and a resolution. Canadian Journal of Occupational Therapy, 69, 5-19.

Welton, D, (2003), "The New Husserl A Critical Reader", Indiana University Press, United States of America.

Xu, J ( Bill), Tsz Ling (Elaine) Chan, and Stephen Pratt, (2017), "Destination Image of Taiwan From the Perspective of Hong Kong Residents: Revisiting Structural Relationships Between Destination Image Attributes and Behavioral Intention", International Journal of Hospitality \& Tourism Administration Published online: 05 Jun 2017. Routledge, PP 1-15. 